\title{
Pathologic Stage IIA Merkel Cell Carcinoma AJCC v8
}

National Cancer Institute

\section{Source}

National Cancer Institute. Pathologic Stage IIA Merkel Cell Carcinoma AJCC v8. NCI

Thesaurus. Code C136884.

Stage IIA includes: T2-3, NO, M0. T2: Maximum clinical tumor diameter more than $2 \mathrm{~cm}$ but equal to or less than $5 \mathrm{~cm}$. T3: Maximum clinical tumor diameter more than $5 \mathrm{~cm}$. NO: No regional lymph node metastasis detected on pathologic examination. M0: No distant metastasis detected on clinical and/or radiologic examination. (AJCC 8th ed.) 